\title{
Obituary
}

\section{Mr. A. Thorburn}

$\mathrm{W}$ ITH the passing of Archibald Thorburn, who died on October 9, at the age of seventy-five years, ornithology has suffered a grievous loss. For a generation his pictures of bird-life held a supreme place in the presentation of our native birds ; and this because he combined the rare gift of scientific accuracy with a sense of composition and colourvalues, rarely attained by any other artist in this field. He knew his birds and loved them, and this goes far to explain his success.

Some of Thorburn's finest work is seen in his pictures of birds which appealed to the sportsman. His illustrations in Lilford's "Coloured Figures of the Birds of the British Islands" made him famous, for they were gems of the first water. He also painted a large number of pictures of pheasants for a great monograph on these birds published in the United States many years ago, as well as most of the coloured plates in the fine monograph of our British gamebirds, written by his old friend J. E. Millais. This was no small tribute to his genius, for Millais himself had won fame in this field.

From his own pen followed two sumptuous books, each in two volumes, illustrated by himself. One of these was devoted to British birds. The other, in every way worthy of its predecessor, followed later, on British mammals. His exquisite pictures of fieldmice and other small rodents and insectivores have never been equalled; and his wonderful drawings of whales seem to vibrate with life. These two books will remain an enduring monument to a great artist. His sure grasp of colour-effects he probably inherited from his father, who in his day enjoyed fame as a painter of miniatures.

The world is the poorer by Thorburn's death. To the wife and son who survive him, his friends and that great host who knew him only by the treasures from his pen and brush, will extend their profoundest sympathy.

W. P. P.

\section{Mr. E. G. Hooper}

Mr. Egbert Grant Hooper was born at Bath on July 2, 1855, and died on September 17, 1935. As a pupil of Frankland at the Royal College of Science, he was a brilliant student and acquired that knowledge of chemistry which he used to such advantage in his later career. In 1878 Grant Hooper joined the Government Laboratory at Somerset House, and was transferred with it to its present quarters off the Strand. While in the Laboratory, he was engaged in food, drug, and water analysis, and assisted the late Dr. James Bell in his pioneer work on the analysis of foods.

In 1881 the tax on malt was changed to a tax on beer, and this gave Grant Hooper the opportunity of utilising his knowledge of the chemistry of brewing.
It is not too much to state that Grant Hooper's small textbook, the "Manual of Brewing", was one of the earliest to consider the art of brewing in the light of the chemical knowledge at the date of its publication. It continued in use by students up to the present century and passed through several editions. It was fortunate too, in this connexion, that Grant Hooper was an expert microscopist. His wide experience enabled him to carry through many official chemical investigations of importance, ranging from the determination of arsenic, to lead in paints.

In 1912 Grant Hooper was appointed Deputy Government Chemist, a position he occupied during the difficult War period until his retirement in 1919. $\mathrm{He}$ was an active member of the principal chemical societies, on which he served by acting on their councils and committees. Among his various offices were those of vice-president of the Institute of Chemistry and chairman of the London Section of the Society of Chemical Industry. Those who worked with him will always remember his readiness to help in diff. culties and to place his wide knowledge at their service.

J. J.F.

\section{Dr. P. K. Kozloff}

THE death is reported of Dr. Petr Kuzmich Kozloff, the well-known Russian explorer, which took place at Leningrad on September 27 at the age of seventy. two years.

Kozloff was a pioneer in the band of travellers, who, combining geographical and archæological exploration in the objective of their expeditions, during the last forty years have traversed the Gobi Desert from end to end, and have restored to Western knowledge the vanished civilisations of Central Asia. Among these, the greatest honour will always be due to Sir Aurel Stein and Sven Hedin ; but the Russian expeditions to Turkestan at the close of the last century were among the first to show the way to the sand-buried cities of these now desert lands, from which English, French, German and Swedish ex. peditions have brought back a priceless store of the treasures of ancient Asiatic art and culture.

Kozloff had already been a member of two important expeditions when he led his own first expedition to Central Asia in 1899. This was followed by a number of explorations in the Gobi Desert in the years preceding the War, of which the most fruitful was that of 1907-9, when he discovered the dead city of Khara Khoto, with its wellpreserved remains of buildings and its evidences of an unknown race, from which he brought back the relics of a library, including writings in an unknown language. Under the Soviet Kozloff made several further expeditions to the Gobi Desert, of which the last was in 1926 . In 1923, with the assistance of the Soviet Government, he published a fully illustrated account of his explorations and of Khara Khoto. 